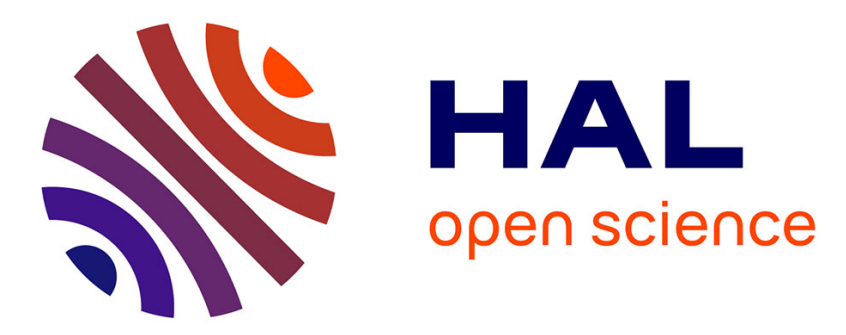

\title{
Improving working conditions in garment supply chains: The role of unions in Cambodia \\ Chikako Oka
}

\section{To cite this version:}

Chikako Oka. Improving working conditions in garment supply chains: The role of unions in Cambodia. British Journal of Industrial Relations, 2016, 54 (3), pp.647-672. 10.1111/bjir.12118 . hal02952169

\section{HAL Id: hal-02952169 \\ https://hal.science/hal-02952169}

Submitted on 29 Sep 2020

HAL is a multi-disciplinary open access archive for the deposit and dissemination of scientific research documents, whether they are published or not. The documents may come from teaching and research institutions in France or abroad, or from public or private research centers.
L'archive ouverte pluridisciplinaire HAL, est destinée au dépôt et à la diffusion de documents scientifiques de niveau recherche, publiés ou non, émanant des établissements d'enseignement et de recherche français ou étrangers, des laboratoires publics ou privés. 


\title{
Improving working conditions in garment supply chains: \\ The role of unions in Cambodia
}

\author{
Chikako Oka \\ chika.oka@royalholloway.ac.uk \\ School of Management \\ Royal Holloway University of London \\ Egham, Surrey \\ TW20 0EX, UK
}

Word Count 9823

\begin{abstract}
Given the disappointing outcomes of private regulation of labour in global supply chains, worker organisation is increasingly seen as the key to better working conditions. This article examines the extent to which unions impact different dimensions of labour standard compliance in Cambodia's exporting garment sector, where unions have grown considerably. Based on unique factory-level data and field-based interviews, this study shows that union presence improves factories' compliance with wage, hours, and leave standards, although the impact is much less significant for safety and health. Moreover, having multiple unions in the workplace does not appear to improve labour conditions.
\end{abstract}

\section{Introduction}

Working conditions in the global garment industry remain dangerous and unhealthy despite various efforts to regulate. Following the Rana Plaza disaster that killed more than 1100 people (mainly workers of garment factories housed in the building) in Bangladesh in April 2013, trade unions have been allowed to register more easily. Could unions have prevented such disasters had they been allowed to operate more freely? More generally, can unions improve all aspects of working conditions for workers toiling at producing garments and other labour-intensive goods destined to consumers in the developed world?

While studying the role and impact of unions in developing countries is crucial to our understanding of what improves working conditions and what unions do in general, very few systematic studies in developing countries exist. Since the seminal work by Freeman and Medoff (1984), there has been a tremendous amount of research on unions and their impact 
on a variety of outcomes including wages, benefits, inequality, job satisfaction, productivity and macro-economic performance (see Bennett and Kaufman 2008 for a comprehensive review). Nonetheless, the focus of union research in Industrial Relations (IR) has been predominantly on developed economies, the bias Freeman $(2008 ; 612)$ recognises: "going beyond the OECD, there is also much to be learned from the experiences of unionism in developing countries, which ... (we) have ignored". This imbalance may distort our understanding of what unions do more generally, given that the majority of the world population resides in developing countries.

On the other hand, there is a voluminous inter-disciplinary literature on labour regulation in global supply chains that focuses almost exclusively on developing countries. The emerging consensus of the literature is the inability of private regulation through codes of conduct and monitoring to consistently deliver progress, notably on labour rights and living wage (Anner 2012; Barrientos and Smith 2007; Egels-Zanden and Merk 2014; Locke 2013; Lund-Thomsen and Lindgreen 2014). Given the disappointing outcomes of buyer-driven regulation, worker organisation is increasingly seen as the key to improve labour conditions in global supply chains (Anner 2012; Seidman 2007). Although the role of organised labour and transnational union networks in global supply chains has received growing attention (Cumbers et al. 2008; Gregoratti and Miller 2011; Helfen and Fichter 2013), there has been no quantitative assessment of unions' impact, evaluating the extent to which unions affect working conditions in global supply chains.

This article seeks to address the lacuna by bringing together different streams of research and examining unions' impact on different dimensions of labour standard compliance. This study draws on quantitative and qualitative evidence from Cambodia's exporting garment sector. The quantitative analysis, based on the comprehensive factory-level data collected by the International Labour Organization (ILO), demonstrates that the presence of unions in the factory helps reduce labour standard violations, although their impact varies with issue areas. Union presence significantly improves compliance with wage, hours and leave standards but less so with regard to safety and health issues. Moreover, having multiple unions in the factory does not help improve compliance. The qualitative analysis illustrates how unions and threat of strikes helped change managerial behaviour and why multiplicity of unions could have counterproductive effects. Overall, the findings underscore the importance of unions in improving working conditions in global supply chains. This article argues that in order to improve labour conditions at the site of production, we need to better understand the potential 
and limits of unions as well as the conditions under which unions can effectively represent workers.

\section{Cambodia's Exporting Garment Sector}

Cambodia's exporting garment sector is characterised by its enormous significance to the economy, predominant foreign-ownership, and dependence on the US market. The sector accounts for approximately $15 \%$ of GDP and $85 \%$ of the country's export in 2010 (Cambodian Ministry of Commerce). As of mid-2013, 412 exporting garment factories were in operation employing 394,262 workers (BFC 2013a). The industry started to emerge around 1994 as investors from Hong Kong, Taiwan, Malaysia and Singapore sought to take advantage of Cambodia's lack of quota restrictions to the US market (Bargawai 2005). To this day, the industry is dominated by foreign investors, owning about 95 percent of exporting garment factories (Garment Manufacturers Association of Cambodia (GMAC)). The sector grew rapidly after 1997, when Cambodia was granted the Most-Favoured Nation status by the US (Bargawai 2005). As Cambodia's garment export to the US market grew, however, Cambodia came under the quota restrictions with the signing of a bilateral Trade Agreement on Textiles and Apparel in 1999. The majority of Cambodia's garment export has been destined for the US market, although the share has declined to $40 \%$ in 2013 (GMAC).

The ILO's monitoring programme grew out of the trade agreement as it contained a positive incentive related to labour conditions: a clause stipulated that the US would increase Cambodia's export quotas (i.e. access to US market) provided that working conditions in Cambodia's garment sector substantially improved (Polaski 2006). Funded principally by the US government, the ILO started its monitoring operation in 2001. Over time, the Cambodian government has come to see the ILO programme as a niche strategy to promote themselves as an 'ethical producer', while international buyers have come to appreciate the ILO's stamp of approval. This explains why the ILO monitoring programme was renewed even after the expiration of the quota regime, renamed as Better Factories Cambodia (BFC) in 2005.

The growth of the garment sector coincided with the rise of labour union movement in Cambodia, which is another unique feature of the Cambodian case. Since the revision of the labour code in 1997 that incorporates workers' right to freedom of association, the number of workers' unions registered with the Ministry of Labour and Vocational Training grew rapidly. 
The growth of unions is observed at the factory level: among 374 factories monitored by BFC in $2013,45 \%$ had one union, $16 \%$ had two unions and $11 \%$ had three or more unions while $28 \%$ did not have any union (author's calculation based on BFC data). Union multiplicity is also evident at the national level as 37 garment union federations have been established by 2010 (Nuon and Serrano 2010; 72). As for union density, 58 \% of exporting garment sector's labour force is estimated to be unionised, based on the survey of 2000 workers conducted in 2010 (BFC 2013b). The sector's union density is reportedly the highest of all industries across Asia (Nuon and Serrano 2010; 71).

Despite the flourishing of labour unions, the violent crackdown on striking garment workers culminating in five deaths in January 2014 shows that workers' rights are far from being fully respected in Cambodia. Union leaders continue to face intimidation, harassment and threats as they try to organise and represent workers (Arnold and Toh 2010). Workers in many of the countries producing garments or other labour-intensive goods face similar challenges as they seek to organise and voice their demands. In Bangladesh, despite the amendment of law enabling unions to register, workers continue to face intimidation and harassment by employers when they try to organise. (Human Rights Watch 2014). On the other hand, state institutions in Cambodia including the Labour Inspectorate and Court are plagued by corruption and incapacity (Hall 2000). Such institutional environment often found in developing countries makes Cambodia a relevant case to explore the role of unions in improving labour conditions.

Although Cambodia's exporting garment sector has been extensively studied given the ILO's unique experiment, the role of labour unions has not received sufficient attention. Existing studies have examined the link between the trade agreement and labour conditions (Kolben 2004; Polaski 2006), the sector's working conditions and workers' rights in general (Arnold and Toh 2010; Miller 2007; Shea et al. 2010), the ILO monitoring programme (Oka 2014; Stanford Law School and Worker Rights Consortium 2013), the role of buyers (Oka 2010a\&b), human resource management innovations (Ang et al. 2012), and the role of shop stewards and liaison officers (Rossi and Raymond 2011). While Gregoratti and Miller (2011) examine international framework agreements in the Cambodian context, this study is unique given its exclusive focus on unions and combination of quantitative and qualitative methods.

\section{Literature}




\section{Labour in Global Supply Chains}

The voluminous literature on private labour regulation in global supply chains has identified both potential and limits of corporate-driven regulation through codes of conduct and monitoring. Private regulation has enabled basic improvements in visible and tractable issues notably safety and health (Barrientos and Smith 2007; Locke 2013). Labour conditions in factories producing for visible and reputation-conscious buyers tend to be better than conditions in less visible supply chains (Lund-Thomsen and Nadvi 2011; Oka 2010a\&b). When such buyers closely engage with suppliers, working conditions can substantially improve (Frenkel and Scott 2002; Locke and Romis 2007; Locke et al. 2009). Nevertheless, the limits to private regulation have also become apparent as it has had little impact on workers' rights to organise and living wage (Anner 2012; Barrientos and Smith 2007; EgelsZanden and Merk 2014; Locke 2013; Lund-Thomsen and Lindgreen 2014). Given the disappointing outcomes, worker organisation is increasingly seen as the key to improve labour conditions in global supply chains (Anner 2012; Seidman 2007).

More recently, there is a burgeoning literature focusing on the role of labour in global supply chains. Scholars have examined how the nature of supply chains and labour's position within the chains shape labour agency and strategy (Lund-Thomsen 2013; Posthuma and Nathan 2010; Riisgaard and Hammer 2011; Quan 2008). Others have evaluated how global framework agreements and transnational union networks have influenced labour rights and working conditions (Cumbers, Nativel and Routledge 2008; Gregoratti and Miller 2011; Helfen and Fichter 2013). These studies tend to emphasise that developing independent labour organisation at the local level is an important condition for effectively countering the power of multinational corporations and improving the lives of workers. Nevertheless, the existing research is predominantly based on case studies and qualitative evidence, making it difficult to systematically assess the impact of unions on different dimensions of working conditions, the lacuna this article seeks to address.

\section{Unions and Legal Compliance}

The IR literature provides insight into the question of why and how union development might affect working conditions. The seminal work by Freeman and Medoff (1984) identified two faces of labour unions: the monopoly face and collective voice face. While the former raises 
wages beyond competitive levels, the latter provides workers with collective voice to communicate with management. The collective voice of unions helps solve the externality problem by providing 'public goods' such as safety conditions that affect all the employees and thus individuals have little incentive to act alone (Ibid.). Moreover, unions help workers express their concerns and reveal true preferences by providing protection from employers' arbitrary behaviour and reprisals (Ibid.). Unions motivated by improving the welfare of their members should therefore act to improve conditions that affect all workers.

Studies have generally found positive relationships between union variables and various aspects of legal compliance including access to legally mandated benefits, safety and health, contract, and discrimination. Unions are found to have a 'facilitation effect' as they provide information and enable workers to access to mandated benefits and indemnity claims in the US (Budd and McCall 1997) and in the UK (Hirsch et al. 1997). As for safety and health, Weil (1991 \& 1992) found unionised workplaces to enforce OSH regulation more vigorously than non-unionised workplaces in manufacturing and construction industries in the US. Unionised firms are also more likely to comply with law and provide written details in employment contract based on the UK data (Brown et al. 2000). Moreover, high levels of unionisation are related to a lower incidence of employers' age discrimination in New Zealand (Harcourt et al. 2004).

While the existing research on unions and employers' legal compliance has shown a generally positive relationship, it has predominantly focused on developed economies. This bias may lead to an erroneous understanding of what unions do in low-income countries, where the majority of the world population resides. Given that workers and unions in developing economies face different sets of constraints and opportunities, they may well act differently from their counterparts in the developed world, as discussed below.

\section{Income Level and Working Conditions}

"In poor economies, a union may do no more than attempt to alter wages and leave the rest of the employment contract unchanged. However, as economies become richer, unions respond to their members' concerns over other aspects of the employment relationship" (Pencavel 2008; 445). This observation reflects a stark choice between wage and non-wage aspects of conditions faced by workers in developing countries. 
The theory of compensating wage differentials posits that there is a trade-off between wage and non-wage characteristics of jobs. Unpleasant working conditions are compensated by wage premiums, ceteris paribus. Conversely, if workers want better working conditions, they can 'pay' for it by accepting lower wages, and the extent to which workers are willing to 'pay' for safer conditions is likely to vary with the income level (Flanagan 2006; 42). Rising incomes and wages increase the value of a worker's time and the cost of accidents, and as a result, demand for safety goes up (Ibid.). A comprehensive review of mortality/injury risk premium studies around the world has found that demand for workplace safety increases with income (Viscusi and Aldy 2003). In other words, while workers in developed countries can afford and prefer to 'pay' for safer conditions, their counterparts in developing countries may tolerate unsafe and unhealthy conditions as they badly need money wages. A recent largescale survey of managers and workers in Vietnam's garment industry underscores the importance of money wages to workers, although safety and health issues are also found to significantly affect workers' life satisfaction (Domat et al. 2013).

Thus, to the extent that workers value money wages more than other aspects of working conditions in low-income countries, the union effect on legal compliance is likely to vary. If unions concentrate their effort on raising wages, union effect on legal compliance is likely to be limited. Nonetheless, unions may well fight for legal compliance given the lack of enforcement and widespread violations in developing countries. In this case, compliance with wages and benefits is likely to be prioritised over issues such as safety and health.

\section{Multi-unionism}

Another stream of the IR literature relevant to this study concerns multiplicity of unions, or "multi-unionism" defined as situations where "two or more unions negotiate with the employer" (Akkerman 2008; 445). Multi-unionism is known to heighten inter-union rivalry, or competition among unions to attract members (Ross and Hartman 1960). The existing literature on multi-unionism has focused on how divided union movements increase strike activity at the firm level (Akkerman 2008; Clegg 1976; Machin et al. 1993; Metcalf et al. 1993; Ross and Irwin 1951). Nonetheless, there is very little research on how multi-unionism affects labour conditions. 
A notable exception, Machin et al. (1993) investigated the impact of multiple unions on wages in the UK, drawing on the model of Horn and Wolinsky (1998). The model hinges upon the substitutability of different groups of workers. If bargaining groups are substitutes, management may follow 'divide and rule' strategy and substitute one group of workers by another, weakening workers' leverage. When different groups are complements, however, they are better off bargaining separately. Machin et al. (1993) found a generally positive relationship between multiple unions bargaining separately and wage levels. This can be explained by the fact that multi-unionism in the UK was not driven by political splits but rather by heterogeneous groups of workers, who were complements rather than substitutes (Akkerman 2008).

This logic can be applied to the impact of multi-unionism on employers' labour standard compliance. In Cambodia's exporting garment sector, where workers are relatively homogeneous and skill levels are rather low, workers are substitutes rather than complements. Multi-unionism in this context is likely to weaken worker leverage vis-à-vis management and to negatively affect labour conditions.

\section{Methods and Data}

\section{Mixed Method}

This study employs both quantitative and qualitative methods to exploit the strengths of each method and complement one another. While the quantitative method helps establish statistical relationships between variables and identify whether and how much each variable matters, the qualitative method can uncover the causal processes underlying those relationships by showing why and how those variables lead to the outcome (Brady and Collier 2004). Moreover, in-depth field-based research provides important information about the nature of the underlying phenomenon that cannot be known by simply looking at the data.

The quantitative analysis draws on the wealth of factory-level information collected by BFC. One of the advantages of the BFC data is its industry-wide coverage, which eliminates the problem of selection bias. This is because the Cambodian government requires all garment factories seeking export licenses to submit to BFC monitoring, allowing BFC monitors access to virtually all exporting garment factories in the country. While the ILO has been monitoring garment factories since 2001, monitoring data have been systematically stored since end-2005. 
The full sample covers 579 factories from 2006 to 2013 with 2839 observations. This constitutes an unbalanced panel, as factories entered and exited during the sample period. The number of factories in operation in a given year fluctuated between 300 and 400 .

The qualitative analysis is largely based on the author's field research carried out in Phnom Penh in the summers of 2007 and 2008. The author conducted 61 field-based interviews with factory managers, union federation leaders, buyer representatives, government officials, labour activists, industry consultants and foreign donors. Moreover, the author accompanied BFC monitors during factory visits, attended meetings, workshops, and buyers' forums, which helped understand the context and nuances. This primary research has been complemented by secondary research of recently published documents and materials.

\section{BFC Monitoring}

BFC monitors conduct un-announced visits of all exporting garment factories once every eight to twelve months. Factory visits by a pair of BFC monitors span an entire day or longer for larger establishments. The process includes on-site inspection, meetings with human resource managers, union leaders, and shop stewards as well as interviews with workers. Copies of pay slips and hour records are collected for verification. BFC monitors check factories' status of compliance (compliance or non-compliance) with nearly 400 detailed standards mainly based on the national labour law and regulations and prepare a monitoring report to be accessed by authorised buyers. ${ }^{1}$ As BFC monitors have no enforcement power, buyers often act as a virtual enforcement authority by requiring suppliers to address important non-compliance issues (Oka 2010a).

The monitored issue categories consist of wage (e.g. record keeping, correct payment, deduction), hours (e.g. normal working hours, over time, holiday work), leave (e.g. holidays, annual, special, sick, and maternity leave), contract (e.g. internal regulations, duration and termination of contract), labour relations (e.g. shop stewards, liaison officers, and collective agreements), welfare (e.g. drinking water and sanitation facilities), occupational safety and health (OSH) (e.g. policy, accidents, emergency, first aid, protective measures, lighting, heat, noise, hazardous materials), and fundamental rights (e.g. child labour, forced labour, discrimination, freedom of association). ${ }^{2}$ When the factory is deemed out of compliance with 
a certain item, monitors make a suggestion for improvement. In general, fewer suggestions or non-compliance items indicate better working conditions.

Nevertheless, the literature cautions against blindly accepting results of compliance monitoring, as supplier factories have learned the tricks of hiding violations and passing audits without fundamentally altering their behaviour (Egels-Zanden 2007; Hoang and Jones 2012). In fact, a recent report jointly compiled by Stanford Law School and Worker Rights Consortium (2013) criticises some of BFC's monitoring practices. While their critiques centre on BFC's lack of transparency and responsiveness to workers, they also point out weaknesses in the monitoring procedures. The report criticises BFC monitors for not systematically interviewing workers off-site and allowing a long waiting time. Although BFC visits are unannounced, monitors may be kept waiting for up to 45 minutes at the factory gates. This practice may lead to under-reporting of violations regarding easy to rectify issues notably safety and health (e.g. emergency exit doors).

Notwithstanding these weaknesses, the compliance data collected by BFC monitors are likely to be superior to those compiled by private auditors. First, BFC monitors are not directly paid by factories or buyers, reducing the conflict of interests often seen in private auditing (Seidman, 2008). Second, unlike some commercial auditors detached from local contexts and unable to talk directly to stakeholders, BFC monitors are locally hired Cambodian nationals who understand the language and local context, increasing their sensitivity and effectiveness as monitors. Third, BFC monitors are hired through competitive procedures, extensively trained, and well-equipped. Furthermore, the fact that the trend in compliance deteriorated in recent years shows that the data captures the underlying phenomenon as discussed below.

\section{Data}

Table 1 shows the evolution of average compliance rates (where a hundred signals full compliance under the category) for different issue categories from 2006 to 2013 in Cambodia's exporting garment sector. Several observations can be made regarding the general trend. First, compliance continued to improve even after the end of the MFA in 2004. This means compliance was not solely driven by trade incentives. Second, the sector's compliance performance resisted the global financial crisis that badly hit the sector in 2009- 
2010. In fact, compliance performance peaked in 2009-2010 at the height of the crisis. Third, compliance performance deteriorated in the 2011-2013 period, which corresponds with economic recovery. BFC's $30^{\text {th }}$ Synthesis Report notes that this deterioration may be partly caused by the growth of the industry "....as managers struggle to keep up with a surge in orders" (BFC 2013a; 2).

\section{--- Table 1 About Here ---}

While the general trend applies to all issue categories, wage, leave contract, labour relations tend to outperform OSH, welfare, and hours. While the average compliance rate under OSH ranks persistently the lowest, this is partly because OSH category has the largest number of checklist items and partly because some of the items are not easy to comply with (e.g. provision of adjustable chairs with backrests for workers who work sitting down), making full compliance harder to achieve. Non-compliance with hours and welfare also tends to persist. Other researchers confirm that involuntary and excessive overtime as well as lack of welfare provision (e.g. childcare facilities) are the most often cited compliance problems in the sector (Shea et al. 2010; 99).

The generally high average compliance rates (calculated as the number of items in compliance over total number of monitored items) mask actual variation in compliance. In order to maximise variation in the dependent variable, the number of violations, or noncompliance items per category is used as the dependent variable in regression analysis. OSH and welfare categories are combined in the regression analysis as they cover similar issues and they are highly correlated.

Table 2 shows the number of unions in the sample. Active unions are present in $76 \%$ of observations, ranging from one (42\%) to six unions or more $(2 \%)$. The presence of union is captured by a dummy variable, which takes the value of one if at least one union is present in the factory, and zero otherwise. Multi-unionism is captured by the number of unions in the establishment. Both of the union variables are lagged by one period to take account of the time it takes for a union or multiple unions to influence working conditions and to clarify the direction of causality. The union presence and number variables are correlated at 0.61 , but the variance inflation factor is less than two, indicating that the degree of multicollinearity is not important. 
Other key variables that are found to affect the level of labour standard (non) compliance, namely the age and size of firm and the presence of reputation-conscious buyers are included in the regression analysis. The age of the establishment is likely to be related to management's learning about the cost and benefit of compliance over time. It is also likely to be correlated with factors that enable them to survive such as management capability and reputation (Weil and Mallo 2007). Given the lack of precise data on age, the total number of BFC monitoring visits since 2001 is used as a proxy. A firm's size is likely to affect compliance as larger firms tend to have more financial capacity to invest in facilities and better working conditions than smaller firms. Moreover, given that size increases employee alienation and supervisory costs, larger establishments are more likely to see the benefit of respecting labour standards to minimise the source of disputes and monitoring cost (Bryson et al. 2007). The natural logarithm of total number of employees measures the size of the establishment.

The type of buyers the factory is producing for has been found to influence the level of labour standard compliance (Oka 2010a\&b). As global apparel brands and retailers targeted by activists and the media have learned to regulate their suppliers, this has translated into the gap in compliance levels between factories producing for 'reputation-conscious buyers' and others without such buyers (Ibid.). While most of the major buyers sourcing from Cambodia have joined BFC by now, it has been a gradual process of convincing these buyers to join the programme, which entails paying fees to view BFC monitoring reports and participating in stakeholder forums. 14 well-known brands and retailers that joined BFC at its inception are those with a higher stake in improving labour conditions in Cambodia's exporting garment factories, given their global visibility and important presence in the country. These are categorised as BFC original buyers, and observations where at least one such buyer is present in the factory takes the value of one and zero otherwise. This type of buyer is present in $60 \%$ of observations in the sample. While almost all factories produce for multiple buyers, supplying at least one demanding buyer shows that the factory was able to satisfy the buyer's compliance requirement to obtain orders (Oka 2012).

\section{Regression Analysis}

Models 
First of all, a series of pooled ordinary least squares (OLS) are estimated. ${ }^{3}$ As shown in Equation (1), a factory's level of non-compliance for each issue category is a linear function of the vector $\mathrm{X}$ of independent variables (the presence and number of unions) for factory $\mathrm{i}$ at time t-1 (lagged by one period) and the vector $\mathrm{Y}$ of control variables (age and size of factory, BFC original buyer) for factory $i$ at time $t$. In addition, the vector $\mathrm{Z}$ of year dummy variables has been added to control for systematic time effects such as macroeconomic shocks and policy changes. Standard errors are clustered on factory to take account of repeated observations.

$$
\text { Non-compliance }_{\text {it }}=\alpha+\mathrm{X}_{\mathrm{it}-1} \beta_{1}+\mathrm{Y}_{\mathrm{it}} \beta_{2}+\mathrm{Z}_{\mathrm{t}} \beta_{3}+\varepsilon_{\text {it }}
$$

The major advantage of panel data is the ability to control for confounding factors and tease out causality (Angrist and Pischke 2009). To control for time-variant omitted variables, a one-period lag of the dependent variable, or AR(1) dynamics, is introduced as follows:

$$
\text { Non-compliance }_{\text {it }}=\alpha+\mathrm{X}_{\mathrm{it}-1} \beta_{1}+\mathrm{Y}_{\mathrm{it}} \beta_{2}+\mathrm{Z}_{\mathrm{t}} \beta_{3}+\text { Non-compliance }_{\mathrm{it}-1} \beta_{4}+\varepsilon \text { it }
$$

Finally, fixed effects, represented by $\mathrm{F}_{\mathrm{i}}$, are incorporated to control for time-invariant omitted variables. Unlike the other two models, the fixed effects model uses the time series information within-case only, thereby eliminating any factory-specific effects. Lagged dependent variables and fixed effects models should be estimated separately and used as a robustness check, as broadly similar results using alternative models provide stronger support to the findings (Ibid.: 245).

$$
\text { Non-compliance }_{\text {it }}=\alpha+\mathrm{X}_{\mathrm{it}-1} \beta_{1}+\mathrm{Y}_{\mathrm{it}} \beta_{2}+\mathrm{Z}_{\mathrm{t}} \beta_{3}+\mathrm{F}_{\mathrm{i}} \beta_{4}+\varepsilon_{\text {it }}
$$

\section{Estimation Results}

Table 3 presents the estimation results with the number of non-compliance items under each issue category (wage, hours, leave, contract, labour relations and OSH-welfare) as the dependent variable. As discussed above, three models have been estimated for each issue category. The first columns show the pooled OLS models. The second columns introduce the lagged dependent variable, or AR(1) dynamics. The number of non-compliance items in the previous period is positively and very significantly related to the number of violations in the current period across issue categories, indicating a substantial persistence in compliance 
performance. The third columns incorporate fixed effects, which focus on changes in noncompliance behaviour within the same factory.

--- Table 3 About Here ---

Union presence is negatively related to the number of non-compliance items across all models and all issue categories. For wage, hours, and leave, union presence is consistently significant at least at the 0.05 level across different model specifications, while the union effect is more equivocal for contract, labour relations, and OSH-welfare. The estimation results provide strong support to the notion that union presence in the workplace reduces labour standard violations, especially with regard to wage, hours, and leave. Unions do not appear to prioritise safety and health issues, in line with the literature on risk premiums and income levels.

In contrast, union number is generally positively related to the number of labour standard violations across models and issue categories (except labour relations). This is not due to collinearity with union presence, as the results remain similar even when union presence is excluded from the regressions. While the union number variable generally lacks statistical significance, it is consistently significant for contract, indicating that having more unions in the workplace increases violations with regard to contract standards. This can be explained by the fact that abuse of short-term contracts and outright termination of contracts are common anti-union tactics in the industry (Arnold and Toh 2010). As the number of unions operating in the factory increases, so does the probability of management taking such measures. Overall, the results indicate that having multiple unions in the same workplace does not help reduce labour standard violations; rather, it can be counterproductive. ${ }^{4}$

The buyer variable is negatively associated with the number of non-compliance items in a consistent and significant manner, corroborating existing findings. The presence of BFC original buyer is highly significant for the pooled OLS and AR(1) models but not for the fixed effects model, partly because of the stable nature of the variable within factory observations. Moreover, these buyers may simply select better performers rather than help improve supplier compliance (Oka 2012), which may explain the lack of explanatory power for within-firm changes. Nonetheless, it is worth noting that the buyer variable is clearly significant in the fixed effect model for OSH-welfare, suggesting that buyer presence does help supplier factories improve safety and health more than other issues, in line with the literature on private labour regulation. 
The size of factory is negatively and significantly related with violations with regard to wage, leave, contract, and OSH. Nonetheless, the size effect loses significance and even changes signs in some of the fixed effects models. This indicates that size captures factoryspecific factors such as capacity that is positively associated with compliance performance and varies across factories. When the same factory increases in size, however, it can increase violations, in particular with regard to hours. The age of factory has mixed signs and generally lacks significance, confirming the mixed effects age has on the level of (non-)compliance. The pooled OLS and AR(1) models that estimate the effect of older factories have positive signs (except hours) whereas the fixed effects models that measure within-factory learning over time have negative signs. The results thus indicate that older factories tend to violate labour standards (notably OSH standards possibly owing to older facilities and equipment), whereas factories become better at complying with standards (wage and leave in particular) as they age and learn.

\section{Qualitative Analysis}

While the above quantitative analysis has clarified the statistical relationships between union variables and the level of labour standard (non-)compliance, it has not answered the question of why and how union presence and numbers affect working conditions. The purpose of this qualitative section, therefore, is to understand how unions affect management's responses regarding different aspects of working conditions. This section is based on 61 field-based interviews with various stakeholders, of which 21 with factory managers and seven with union federation leaders. ${ }^{5}$

In Cambodia's exporting garment sector, the growth of unions has intensified competition among unions trying to attract members and led to aggressive tactics notably strikes, according to the labour officer of the employers' association, GMAC. When a problem arises, workers go from one union to another, looking for the most helpful union to solve their problem. Trying not to lose 'face' and members, unions fight hard against management even if the workers' demand is unreasonable. While the multiplicity of unions may have empowered workers as they can pick and choose the union that represents their interest, it has intensified union rivalry and increased strikes. 
The rise of unions, widespread strikes and important penalty imposed by buyers for late delivery appear to have prompted some factory managers to improve compliance. Empty shelves in shops caused by late shipment are buyers' nightmare, explains an industry consultant. Moreover, in the trend-sensitive fashion industry, shipments arriving late in the season are of little value. Consequently, if factories fail to deliver on-time, almost all buyers require garments to be transported by air freight instead of ship, wiping out all the profits of garment factories. In addition, serious delays are further punished by discount. This is why striking workers almost always obtain their pay during the strike action as part of the condition to go back to work. "Employers are desperate to get workers back to work. This is 'on-time industry", notes the labour officer of GMAC.

Nearly 70 percent of managers interviewed cited avoiding problems with unions and preempting strikes as one of the main motivations to improve compliance. The manager of a large Hong Kong-owned factory says: "GMAC sends many strike reports about what went on in other factories. I take preventative measures and comply $100 \%$ with the labour law to avoid problems". The manager of another Hong-Kong owned factory concurs saying "workers know about the labour code". This factory experienced a major dispute in 2007, which turned into a high profile case involving a global union federation and global buyers such as Inditex and $\mathrm{H} \& \mathrm{M}$.

Increasingly, however, workers' demands centre on conditions that exceed legal compliance, notably leave and pecuniary conditions. Employers preoccupied with preempting disputes offer conditions that exceed legal requirements in order to avoid problems with unions. A large Singaporean-owned factory provides extra holidays around the Khmer New Year, in addition to respecting the legal requirement of paid annual leave and paid sick leave. Moreover, in response to worker demands, the $\$ 6$ cost of living allowance has been added to the base wage, which is used to calculate overtime and various bonuses. Similarly, a large Malaysian-owned factory implements the 'best practice'. To get workers to cooperate, the management gives the minimum wage straight to probationary workers, provides extra food allowance for overtime, and offers attendance bonus of US\$5 despite some unauthorised absence, all of which exceed the legal requirements.

Nevertheless, union power has not translated into even progress in working conditions. Recent incidents of mass fainting in the sector involving 1973 workers in 12 factories indicate persistent problems with safety and health (BFC 2012). Fainting is likely to be caused by a 
combination of heat stress, chemical exposures, noise, inadequate hygiene and nutrition as well as excessive overtime (Ibid.). While disputes and strikes are widespread, they rarely centre on OSH issues, as workers and unions tend to prioritise pecuniary issues and leave. The interviewed factory managers talked about increasing benefits and holidays as a way to keep workers happy, but none of them mentioned improving safety and health was important to appease workers. In fact, workers themselves pay insufficient attention to certain safety and health issues. For instance, workers are reluctant to use protective equipment and needle guards as they slow down work and reduce piece rate, according to multiple factory managers.

On the other hand, union rivalry has compromised unions' effectiveness as it allows management to 'divide and rule' by playing one union against another. This has been compounded by a deep cleavage between pro-government union federations and proopposition/independent union federations. All union federation leaders mentioned 'bad' unions and how they created problems and hampered their activities. "They (pro-government unions) buy off members with phones and money so workers switch or join (their unions)", says the President of Coalition of Cambodian Apparel Workers Democratic Union (CCAWDU), independent union federation. "Yellow unions pretend to have members and threaten to go on strike. Employers pay and try to stop strikes and divide unions. Governmentsupported unions obstruct and threaten independent unions", notes the President of National Independent Federation Textile Union of Cambodia (NIFTUC). On the other hand, the President of Khmer Youth Trade Union Federation (KYFTU), known to be linked to the ruling party, remarks "unions affiliated with the opposition party go on strike to show their strength and try to get workers' support and collect votes for elections".

Such politically divided union movement has obstructed collective bargaining and hampered sector-wide wage negotiations. Multiplicity of unions makes it difficult for unions to obtain the most representative status, which is necessary to negotiate and sign collective bargaining agreements with employers. Moreover, government-supported unions often threaten or actually go on strike at the factory-level, but they rarely lead or participate in sector-wide rallies and demonstrations demanding wage increases. The mass demonstrations demanding the minimum wage increase in 2014 were led by the opposition-linked and independent union federations, while pro-government union federations remained silent.

In sum, the rise of unions combined with the threat of strikes appears to have altered power asymmetry between workers and factory management in favour of the former. Some factory 
managers seek to avoid problems with unions by respecting labour standards and offering better conditions to workers. Nevertheless, it has not translated into even progress given that workers and unions tend to focus on pecuniary and leave issues and neglect safety and health. On the other hand, the divided union movement has compromised unions' effectiveness in promoting collective bargaining and broader pro-worker agenda as they compete for members and obstruct each other's activities.

\section{Conclusion}

Despite the spread of private labour regulation in global supply chains, dismal working conditions and tragic incidents of factory fires and building collapses continue to plague the global garment industry. Amid the disappointing outcomes of private regulation, growing attention is paid to the role of worker organisation. Is union development the key to better working conditions in global supply chains? By drawing on unique data from Cambodia's exporting garment sector, this study has shed light on the role of unions in improving working conditions.

One of the key findings of this article is that the presence of unions helps reduce labour standard violations in general, but union presence affects certain dimensions of labour standards more than others. The regression analysis shows union presence is highly significant with regard to wage, hours, and leave standards, but much less so vis-à-vis safety and health issues. The qualitative evidence also illustrates how management seeks to placate workers by providing extra cash and leave beyond legal requirements but not by improving safety and health. The finding is consistent with the literature on demand for workplace safety and different levels of income: workers in developing countries tend to prioritise pecuniary conditions and tolerate unsafe and unhealthy conditions as they badly need money wages.

Another novel finding is that multiplicity of unions does not help reduce labour standard violations. The regression analysis shows that the number of unions in the workplace is not related to the number of non-compliance items. The qualitative analysis shows that competition among unions has increased strikes, in line with the literature on multi-unionism. Although the threat of strikes may have weakened managerial authority, rivalry among politically divided unions has been prone to management's 'divide and rule' strategy, hampering effective representation of workers. 
These findings have important implications for different streams of research. By demonstrating what unions do depends on the level of development, this study contributes to the IR literature on union impact, which tended to be biased toward developed economies. Moreover, this study supplies much needed systematic evidence on union impact to the predominantly qualitative literature on labour in global supply chains. Indeed, unions play a key role in improving working conditions at the site of production. Nevertheless, the fact that unions tend to prioritise pecuniary issues over safety and health suggests that encouraging unionisation alone is not sufficient to eliminate dangerous and unhealthy working conditions prevalent in the global garment industry. It would require much stronger enforcement by public as well as private actors. In the aftermath of the Rana Plaza disaster, the Bangladeshi government has overhauled its regulation while buyers have come together to create institutional mechanisms to inspect and remedy building safety (i.e. Accord and Alliance). It remains to be seen whether and how they can effectively address the deep-rooted problem.

Furthermore, Cambodia's rich experience on multi-unionism provides important policy lessons to countries that have begun to ease the restriction on worker organisation, such as Bangladesh. The Cambodian case illustrates that multiplicity of unions in a weak institutional environment is conducive to divided union movement. Notwithstanding the importance of giving choice to workers, union democracy needs to be balanced with the need to collectively promote and negotiate better conditions for all workers.

Finally, one key theoretical implication of the findings concerns potential complementarity between union-driven and buyer-driven regulation of labour standards in global supply chains. Interestingly, the pattern of union impact on working conditions stands in sharp contrast to that of buyer influence, which tends to improve safety and health issues more than others. Scholars have examined how state and private regulation interact and complement each other (Amengual 2010 \& 2014; Kim 2013; Locke et al. 2013). This article suggests that complementarity also exists between different private actors-unions and buyers-in enforcing labour standards as the former tends to prioritise pecuniary conditions while the latter emphasises safety and health issues. This is a promising avenue that should be explored in future research.

Overall, this study underscores the need to encourage unionisation to improve working conditions in global supply chains. Equally importantly, it indicates the need to move beyond simply calling for worker organisation and to make headway toward understanding unions' 
potential and limits as well as the conditions under which unions can effectively represent workers and improve their welfare in global supply chains. 


\section{Notes}

1. BFC monitoring is more comprehensive than buyer or third-party audits that tend to focus on key issues. The content largely overlaps as most buyers' codes include compliance with national regulation. Some buyers have stopped their own monitoring and replaced it with BFC monitoring.

2. As the category of fundamental rights covers interference with freedom of association, using it as the dependent variable causes endogeneity: the factory's tolerance for freedom of association affects the presence and number of unions. Anti-union discrimination is common in the industry and unfair dismissal of union leaders is one of the major sources of collective disputes. For this reason, the category of fundamental rights is not included in the analysis.

3. To take account of the skewed nature of the data, a series of negative binominal regressions have also been estimated, which produced similar findings. Given the ease of interpretation, the OLS estimates are reported here.

4. While the possibility of reverse causality (i.e. non-compliant factories tend to have more unions) cannot be excluded, the fact that the union variables are lagged and that union presence is negatively related to non-compliance makes it less plausible. It might be argued that in workplaces with multiple unions competing for members, workers are more aware of their rights and thus they tend to expose more violations. Nevertheless, BFC's monitoring procedure is not complaint-based and thus it is less likely to be affected by this.

5. The selection of factories was random in the sense that it followed the pattern of BFC monitoring visits, whose schedule was not influenced by any particular factory characteristics. While all factories except one are foreign-owned, this is not unrepresentative as $95 \%$ of Cambodia's exporting garment factories are foreign-owned. Moreover, I interviewed seven leaders (including one former leader) of the following union federations: CCAWDU (Coalition of Cambodian Apparel Workers Democratic Unions), FTUWKC (Free Trade Union Workers of Kingdom of Cambodia), CIUF (Cambodian Industry Union Federation), CUF (Cambodian Union Federation), NIFTUC (National Independent Federation Textile Union of Cambodia), and KYFTU (Khmer Youth Trade Union Federation). These federations were selected for their important presence in the industry and balance in terms of political orientations.

\section{References}

Akkerman, A. (2008). 'Union competition and strikes: The need for analysis at the sector level'. Industrial and Labor Relations Review, 61: 445-459.

Amengual, M. (2010). 'Complementary labour regulation: The uncoordinated combination of state and private regulators in the Dominican Republic'. World Development, 38: 405-414.

(2014). 'Pathway to enforcement: Labor inspectors leveraging linkages with society in Argentina'. Industrial and Labor Relations Review, 67: 3-33.

Ang, D., Brown, D., Dehejia, R., Robertson, R. (2012). 'Labor law compliance and human resource innovation: Better Factories Cambodia'. Review of Development Economics, 16: 594-607. 
Angrist, D. and Pischke, J-S. (2009). Mostly Harmless Econometrics: An Empiricist's Companion. Princeton, NJ: Princeton University Press.

Anner, M. (2012). 'Corporate social responsibility and freedom of association rights: The precarious quest for legitimacy and control in global supply chains'. Politics \& Society, 40: 609-644.

Arnold, D. and Toh, S. H. (2010). 'A fair model of globalization? Labor and global production in Cambodia'. Journal of Contemporary Asia, 40: 401-424.

Bargawai, O. (2005). 'Cambodia's garment industry: Origins and future prospects'. ESAU Working Paper 13. London: Overseas Development Institute.

Barrientos, S. and Smith, S. (2007). 'Do workers benefit from ethical trade? Assessing codes of labour practice in global production systems'. Third World Quarterly, 28: 713-729.

Bennett, J. T. and Kaufman, B. E. (eds.) (2008). What Do Unions Do? A Twenty-Year Perspective. New Brunswick, NJ: Transaction Publishers.

BFC (2012). 'Concrete actions from stakeholders to reduce fainting incidents'. BFC Newsletter, No. 19. March 2012.

(2013a). Thirtieth Synthesis Report on Working Conditions in Cambodia's Garment Sector. ILO \& IFC.

(2013b) Twenty Ninth Synthesis Report on Working Conditions in Cambodia's Garment Sector. ILO \& IFC.

Brady, H. E. and Collier, D. (2004). Rethinking Social Inquiry: Diverse Tools, Shared Standards. Oxford: Rowman \& Littlefield.

Brown, W., Deakin, S., Nash, D. and Oxenbridge, S. (2000). 'The employment contract: From collective procedures to individual rights'. British Journal of Industrial Relations, 38: 611-629.

Bryson, A. Gomez, R., Kretschmer, T. and Willman, P. (2007). 'The diffusion of workplace voice and high-commitment management practices in Britain, 1984-1998'. Industrial and Corporate Change 16: 395-426.

Budd, J. W. and McCall, B. P. (1997). 'The effect of unions on the receipt of unemployment insurance benefits'. Industrial and Labor Relations Review, 50: 478-92.

Clegg, H. A. (1976). Trade Unionism under Collective Bargaining: A Theory Based on Comparison of Six Countries. London: Basil Blackwell.

Cumbers, A., Nativel, C. and Routledge, P. (2008). 'Labour agency and union positionalities in global production networks'. Journal of Economic Geography, 8: 369-387. 
Domat, G. Adler, P., Brown, D., Dehejia, R., and Robertson, R. (2013). 'Do factory managers know what workers want? Manager-worker information asymmetries and pareto optimal working conditions'. Better Work Discussion Paper No. 10. Geneva: ILO \& IFC.

Egels-Zanden, N. (2007). 'Suppliers' compliance with MNCs' codes of conduct: Behind the scenes at Chinese toy suppliers'. Journal of Business Ethics, 75: 45-62.

and J. Merk (2014). 'Private regulation and trade union rights: why codes of conduct have limited impact on trade union rights'. Journal of Business Ethics, 123: 461-473.

Flanagan, R. J. (2006). Globalization and Labor Conditions: Working Conditions and Worker Rights in a Global Economy. Oxford: Oxford University Press.

Freeman, R. (2008). 'What do unions do? The 2004 M-Brane stringtwister edition'. In J. T. Bennett and B. E. Kaufman (eds.), What Do Unions Do? A Twenty-Year Perspective. New Brunswick, NJ: Transaction Publishers, pp. 607-636.

and J. L. Medoff. (1984). What Do Unions Do? New York: Basic Books

Frenkel, S. J. and Scott, D. (2002). Compliance, collaboration, and codes of labour practice: the ADIDAS connection. California Management Review, 45: 29-49.

Gregoratti, C. and Miller, D. (2011). 'International framework agreements for workers' rights? Insights from River Rich Cambodia'. Global Labour Journal, 2: 84-105.

Hall, J. (2000). 'Human rights and the garment industry in contemporary Cambodia'. Stanford Journal of International Law, 36: 119-174.

Harcourt, M., Wood, G. and Harcourt, S. (2004). Do unions affect employer compliance with the law? New Zealand evidence for age discrimination. British Journal of Industrial Relations, 42: 527-541.

Helfen, M. and Fichter, M. (2013). Building transnational union networks across global production networks: Conceptualising a new arena of labour-management relations'. British Journal of Industrial Relations, 51: 553-576.

Hirsch, B. T., Macpherson, D. A. and DuMond, J. M. (1997). 'Workers' compensation recipiency in union and nonunion workplaces'. Industrial and Labor Relations Review, 50: 213-236.

Hoang, D. and Jones, B. (2012). 'Why do corporate codes of conduct fail? Women workers and clothing supply chains in Vietnam'. Global Social Policy,12: 67-85.

Horn, H. and Wolinsky, A. (1998). 'Worker substitutability and patterns of unionisation'. Economic Journal, 98: 484-497.

Human Rights Watch (2014) 'Bangladesh: Protect garment workers' rights'. Available at http://www.hrw.org/news/2014/02/06/bangladesh-protect-garment-workers-rights (accessed May 2014). 
Kim, J. Y. (2013). 'The politics of code enforcement and implementation in Vietnam's apparel and footwear factories'. World Development, 45: 286-295.

Kolben, K. (2004). 'Trade, monitoring, and the ILO: Working to improve conditions in Cambodia's garment factories'. Yale Human Rights \& Development Journal, 7: 79-107.

Locke, R. M. (2013). The Promise and Limits of Private Power: Promoting Labor Standards in a Global Economy. Cambridge: Cambridge University Press. , Rissing, B.A., Pal, T. (2013). 'Complements of substitutes? Private codes, state regulation and the enforcement of labour standards in global supply chains'. British Journal of Industrial Relations, 51: 519-552.

, Amengual, M., Mangla, A. (2009). Virtue out of necessity? Compliance, commitment, and the improvement of labor conditions in global supply chains'. Politics \& Society, 37: 319-351.

and Romis, M. (2007). Improving work conditions in a global supply chain'. MIT Sloan Management Review, 48: 54-62.

Lund-Thomsen, P. (2013). Labor agency in the football manufacturing industry of Sialkot, Pakistan. Geoforum, 44: 71-81. and Lindgreen, A. (2014). Corporate social responsibility in global value chains: Where are we now and where are we going? Journal of Business Ethics, 123: 11-22.

and Nadvi, K. (2011). Cluster, chains and compliance: Corporate social responsibility and governance in football manufacturing in South Asia. Journal of Business Ethics, 93: 201222.

Machin, S., Steward, M., and Van Reenen, J. (1993). 'The economic effects of multiple unionism: Evidence from the 1984 workplace industrial relations survey'. Scandinavian Journal of Economics, 95: 297-296.

Metcalf, D., Wadwsorth, J. and Ingram, P. (1993). 'Multi-unionism, size of bargaining group, and strikes'. Industrial Relations Journal, 24: 3-13.

Miller, D. (2007). "“Business as usual?" Governing the supply chain in clothing post MFA phase out. The case of Cambodia'. Global Union Research Network Discussion Paper No. 6. Gevena: ILO.

Nuon, V. and Seerrano, M. (2010). Building Unions in Cambodia: History, Challenges, Strategies. Singapore: Friedrich-Ebert-Stiftung Office for Regional Cooperation in Asia.

Oka, C. (2010a). 'Accounting for the gaps in labor standard compliance: The role of reputation-conscious buyers in the Cambodian garment sector'. European Journal of Development Research, 22: 59-78. (2010b). 'Channels of buyer influence and labor standard compliance: The case of Cambodia's garment sector'. Advances in Industrial and Labor Relations, 17: 153-183. 
(2012). 'Does better labour standard compliance pay? Linking labour standard compliance and supplier competitiveness'. Better Work Discussion Paper No. 5. Geneva: ILO\&IFC.

(2014). 'Evaluating a promising model of non-state labour regulation: the case of Cambodia's apparel sector'. In D. McCann, S. Lee, P. Belser, C. Fenwick, J. Howe, and M. Luebker (eds.), Creative Labour Regulation: Indeterminacy and Protection in an Uncertain World. Palgrave Macmillan \& ILO, pp. 259-279.

Pencavel, J. (2008). 'Unionism viewed internationally'. In J. T. Bennett and B. E. Kaufman (eds.), What Do Unions Do? A Twenty-Year Perspective. New Brunswick, NJ: Transaction Publishers, pp. 423-458.

Polaski, S. (2006). 'Combining global and local forces: The case of labor rights in Cambodia'. World Development, 34: 919-932.

Posthuma, A. and Nathan, D. (ed.), Labour in Global Production Networks in India. New York: Oxford University Press.

Quan, K. (2008). Use of global value chain by labor organizers. Competition and Change, 12: 89-104.

Riisgaard, L. and Hammer, N. (2011). 'Prospects for labour in global value chains: Labour standards in the cut flower and banana industries'. British Journal of Industrial Relations, 49: 168-190.

Ross, A. H. and Hartman, P. (1960). Changing Patterns of Industrial Conflict. New York and London: John Wiley \& Sons. and Irwin, D. (1951). 'Strike experience in five countries, 1927-1947: An interpretation', Industrial and Labor Relations Review, 4: 323-342.

Rossi, A. and Raymond, R. (2011). Better Factories Cambodia: An instrument for improving industrial relations in a transnational context. Center for Global Development Working Paper No. 256

Seidman, G. (2007). Beyond the Boycott: Labour rights, Human Rights and Transnational Activism. New York: Russell Sage Foundation Press/American Sociological Association.

(2008). 'Transnational labour campaigns: Can the logic of the market be turned against itself?' Development and Change, 39: 991-1003.

Shea, A., Nakayama, M., and Heymann, J. (2010). 'Improving labour standards in clothing factories: Lessons from stakeholder views and monitoring results in Cambodia'. Global Social Policy, 10: 85-110.

Stanford Law School and Worker Rights Consortium (2013). 'Monitoring in the Dark: An Evaluation of the International Labour Organization's Better Factories Cambodia Monitoring and Reporting Program'. Available at 
http://humanrightsclinic.law.stanford.edu/project/monitoring-in-the-dark/ (accessed May 2014).

Viscusi, W. K. and Aldy, J. E. (2003). 'The value of a statistical life: A critical review of market estimates throughout the world'. NBER Working Paper No. 9487.

Weil, D. (1991). 'Enforcing OSHA: The role of labor unions'. Industrial Relations, 30: 20-36. . (1992). 'Building safety: The role of construction unions in the enforcement of OSHA'. Journal of Labor Research, 13: 121-132. and Mallo, C. (2007). 'Regulating labour standards via supply chains: Combining public/private interventions to improve workplace compliance'. British Journal of Industrial Relations, 45: 791-814. 
Table 1. Average Compliance Rates in Cambodia's Exporting Garment Sector 2006-2013

\begin{tabular}{|c|c|c|c|c|c|c|c|c|}
\hline \multirow[t]{2}{*}{ Issue Category } & \multicolumn{8}{|c|}{ Average Compliance Rates } \\
\hline & 2006 & 2007 & 2008 & 2009 & 2010 & 2011 & 2012 & 2013 \\
\hline Wage & 91,1 & 94,1 & 94,6 & 94,9 & 95,1 & 94,7 & 92,7 & 92,5 \\
\hline Hours & 81,6 & 86,4 & 87,1 & 89,7 & 88,9 & 87,3 & 86,2 & 85,0 \\
\hline Leave & 82,6 & 89,2 & 91,6 & 93,4 & 94,5 & 93,0 & 90,5 & 91,8 \\
\hline Contract & 87,7 & 91,3 & 91,7 & 92,8 & 93,3 & 92,7 & 91,3 & 91,2 \\
\hline Labour Relation & 86,1 & 90,4 & 91,0 & 92,3 & 92,6 & 92,0 & 90,9 & 91,1 \\
\hline Welfare & 79,7 & 85,2 & 86,2 & 88,0 & 88,4 & 87,9 & 85,2 & 85,0 \\
\hline $\mathrm{OSH}$ & 79,3 & 83,3 & 84,2 & 86,1 & 86,7 & 85,3 & 82,4 & 81,0 \\
\hline Average $^{a}$ & 84,0 & 88,6 & 89,5 & 91,0 & 91,4 & 90,4 & 88,4 & 88,2 \\
\hline
\end{tabular}

Note: ${ }^{\mathrm{a}}$ This average does not include the category of fundamental rights.

Table 2. Number of Unions in the Sample

\begin{tabular}{ccc}
\hline $\begin{array}{c}\text { Union } \\
\text { Numbers }\end{array}$ & $\begin{array}{c}\text { Number of } \\
\text { observations }\end{array}$ & $\begin{array}{c}\% \text { of } \\
\text { observations }\end{array}$ \\
\hline 0 & 684 & 24 \\
1 & 1179 & 42 \\
2 & 596 & 21 \\
3 & 226 & 8 \\
4 & 65 & 2 \\
5 & 41 & 1 \\
6 or more & 48 & 2 \\
Total & 2839 & 100 \\
\hline
\end{tabular}


Table 3a. Regression Results of Labour Standard Non-compliance for Different Issue Categories (2006-2013)

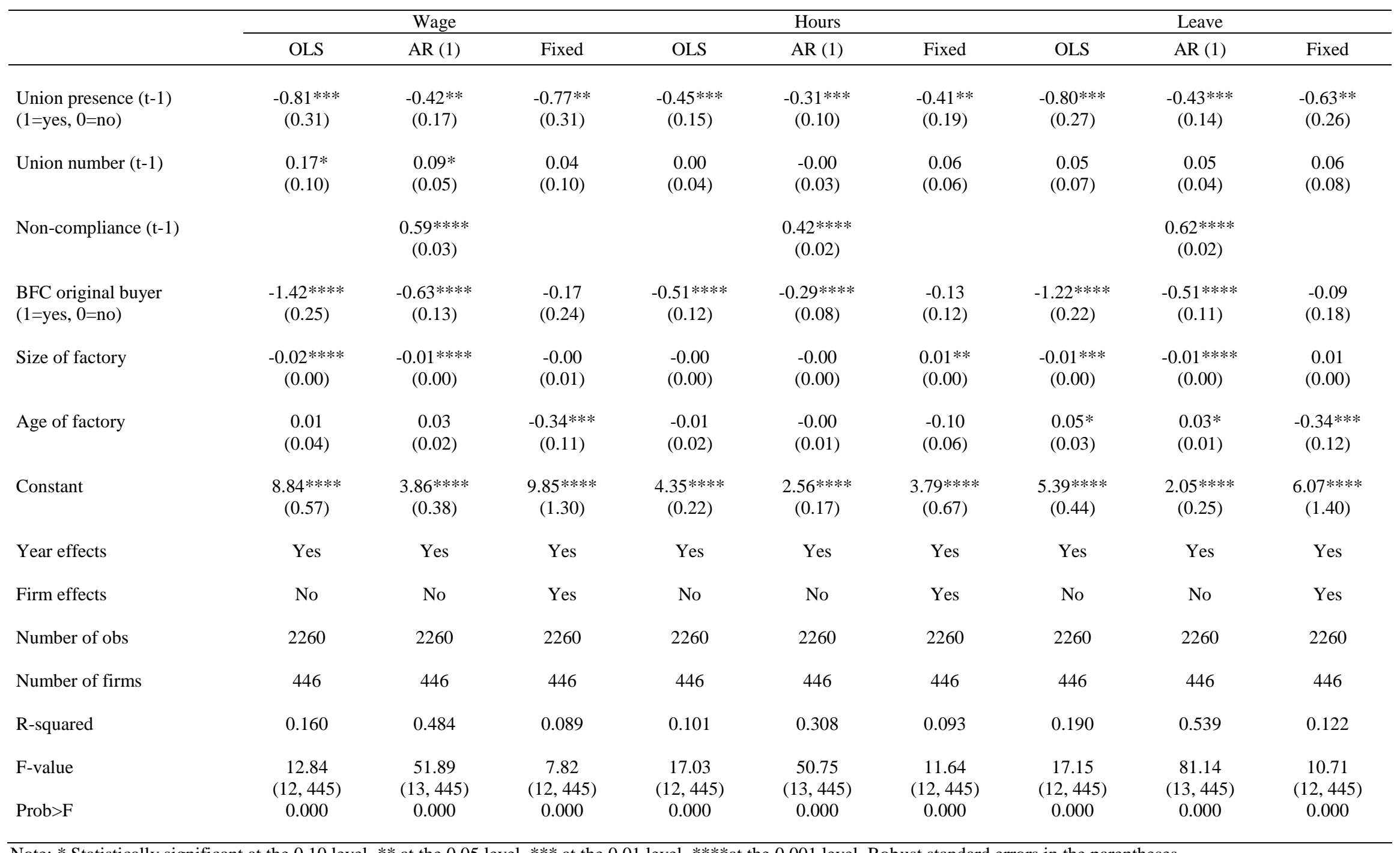

Note: $*$ Statistically significant at the 0.10 level, $* *$ at the 0.05 level, $* * *$ at the 0.01 level, $* * * *$ at the 0.001 level. Robust standard errors in the parentheses. 
Table 3b. Regression Results of Labour Standard Non-compliance for Different Issue Categories (2006-2013)

\begin{tabular}{|c|c|c|c|c|c|c|c|c|c|}
\hline & \multicolumn{3}{|c|}{ Contract } & \multicolumn{3}{|c|}{ Labour Relations } & \multicolumn{3}{|c|}{ OSH-Welfare } \\
\hline & OLS & $\mathrm{AR}(1)$ & Fixed & OLS & $\operatorname{AR}(1)$ & Fixed & OLS & $\operatorname{AR}(1)$ & Fixed \\
\hline $\begin{array}{l}\text { Union presence }(\mathrm{t}-1) \\
(1=\mathrm{yes}, 0=\text { no })\end{array}$ & $\begin{array}{l}-0.27 \\
(0.24)\end{array}$ & $\begin{array}{l}-0.15 \\
(0.14)\end{array}$ & $\begin{array}{c}-0.83 * * * \\
(0.26)\end{array}$ & $\begin{array}{l}-0.36 \\
(0.23)\end{array}$ & $\begin{array}{l}-0.34 * * \\
(0.15)\end{array}$ & $\begin{array}{l}-0.63 * \\
(0.36)\end{array}$ & $\begin{array}{l}-1.28 \\
(1.03)\end{array}$ & $\begin{array}{l}-0.84 * \\
(0.44)\end{array}$ & $\begin{array}{l}-1.72 * \\
(0.92)\end{array}$ \\
\hline Union number $(\mathrm{t}-1)$ & $\begin{array}{l}0.15^{*} \\
(0.08)\end{array}$ & $\begin{array}{l}0.09 * * \\
(0.04)\end{array}$ & $\begin{array}{l}0.22 * * \\
(0.09)\end{array}$ & $\begin{array}{l}-0.03 \\
(0.08)\end{array}$ & $\begin{array}{l}-0.01 \\
(0.05)\end{array}$ & $\begin{array}{c}0.16 \\
(0.10)\end{array}$ & $\begin{array}{c}0.43 \\
(0.34)\end{array}$ & $\begin{array}{c}0.22 \\
(0.15)\end{array}$ & $\begin{array}{c}0.40 \\
(0.32)\end{array}$ \\
\hline Non-compliance (t-1) & & $\begin{array}{c}0.57 * * * * \\
(0.02)\end{array}$ & & & $\begin{array}{c}0.45 * * * * \\
(0.02)\end{array}$ & & & $\begin{array}{c}0.69 * * * * \\
(0.02)\end{array}$ & \\
\hline $\begin{array}{l}\text { BFC original buyer } \\
(1=\text { yes, } 0=\text { no })\end{array}$ & $\begin{array}{c}-0.73 * * * * \\
\quad(0.20)\end{array}$ & $\begin{array}{c}-0.31 * * * \\
(0.11)\end{array}$ & $\begin{array}{l}-0.14 \\
(0.18)\end{array}$ & $\begin{array}{c}-0.54 * * * \\
(0.19)\end{array}$ & $\begin{array}{c}-0.30 * * \\
(0.12)\end{array}$ & $\begin{array}{l}-0.28 \\
(0.24)\end{array}$ & $\begin{array}{c}-6.17 * * * * * \\
(0.86)\end{array}$ & $\begin{array}{l}-2.54 * * * * \\
(0.40)\end{array}$ & $\begin{array}{c}-1.50 * * \\
(0.63)\end{array}$ \\
\hline Size of factory & $\begin{array}{c}-0.02 * * * * \\
(0.00)\end{array}$ & $\begin{array}{c}-0.01 * * * * \\
(0.00)\end{array}$ & $\begin{array}{l}-0.00 \\
(0.00)\end{array}$ & $\begin{array}{c}-0.01 * * * \\
(0.00)\end{array}$ & $\begin{array}{l}-0.00 \\
(0.00)\end{array}$ & $\begin{array}{c}0.01 \\
(0.00)\end{array}$ & $\begin{array}{c}-0.09 * * * * \\
(0.01)\end{array}$ & $\begin{array}{c}-0.03 * * * * \\
(0.01)\end{array}$ & $\begin{array}{l}-0.01 \\
(0.01)\end{array}$ \\
\hline Age of factory & $\begin{array}{c}0.03 \\
(0.03)\end{array}$ & $\begin{array}{l}0.03 * * \\
(0.02)\end{array}$ & $\begin{array}{l}-0.11 \\
(0.08)\end{array}$ & $\begin{array}{c}0.00 \\
(0.03)\end{array}$ & $\begin{array}{c}0.02 \\
(0.02)\end{array}$ & $\begin{array}{l}-0.08 \\
(0.09)\end{array}$ & $\begin{array}{l}0.27 * * \\
(0.13)\end{array}$ & $\begin{array}{c}0.19 * * * * \\
(0.05)\end{array}$ & $\begin{array}{l}-0.41 \\
(0.31)\end{array}$ \\
\hline Year effects & Yes & Yes & Yes & Yes & Yes & Yes & Yes & Yes & Yes \\
\hline Firm effects & No & No & Yes & No & No & Yes & No & No & Yes \\
\hline Number of obs & 2260 & 2260 & 2260 & 2260 & 2260 & 2260 & 2260 & 2260 & 2260 \\
\hline Number of firms & 446 & 446 & 446 & 446 & 446 & 446 & 446 & 446 & 446 \\
\hline R-squared & 0.129 & 0.429 & 0.056 & 0.067 & 0.300 & 0.046 & 0.252 & 0.613 & 0.138 \\
\hline F-value & $\begin{array}{c}13.93 \\
(12,445)\end{array}$ & $\begin{array}{c}96.61 \\
(13,445)\end{array}$ & $\begin{array}{c}6.73 \\
(12,445)\end{array}$ & $\begin{array}{c}6.40 \\
(12,445)\end{array}$ & $\begin{array}{c}36.62 \\
(13,445)\end{array}$ & $\begin{array}{c}4.18 \\
(12,445)\end{array}$ & $\begin{array}{c}24.38 \\
(12,445)\end{array}$ & $\begin{array}{c}203.92 \\
(13,445)\end{array}$ & $\begin{array}{c}14.70 \\
(12,445)\end{array}$ \\
\hline Prob $>F$ & 0.000 & 0.000 & 0.000 & 0.000 & 0.000 & 0.000 & 0.000 & 0.000 & 0.000 \\
\hline
\end{tabular}

Note: $*$ Statistically significant at the 0.10 level, $* *$ at the 0.05 level, $* * *$ at the 0.01 level, $* * * *$ at the 0.001 level. Robust standard errors in the parentheses 
